International Journal of Linguistics, Literature and Translation (IJLLT)

ISSN: 2617-0299 (Online); ISSN: 2708-0099 (Print)

DOI: $10.32996 / \mathrm{ijllt}$

Journal Homepage: www.al-kindipublisher.com/index.php/ijllt

\title{
Nikkei Literature in the State of Mato Grosso do Sul, Brazil
}

Michele Eduarda Brasil de Sá

Professor, Federal University of Mato Grosso do Sul, Campo Grande, Brazil

Corresponding Author: Michele Eduarda Brasil de Sá, E-mail: michele.eduarda@ufms.br

\section{ARTICLE INFORMATION}

Received: November 12, 2020

Accepted: December 15, 2020

Volume: 3

Issue: 12

DOI: 10.32996/ijllt.2020.3.12.2

KEYWORDS

Contemporary Brazilian literature.

Cultural identity. Nikkei literature.

Regional literary production

\section{ABSTRACT}

This research paper presents the preliminary findings of a homonymous project, which aims to study the literary production of nikkei (people of Japanese descent) in the state of Mato Grosso do Sul in Brazil. This project investigates the existence of this production and intends to study it as part of contemporary Brazilian literature. The scope of the research considers the nikkei production as one of the evidences that show the process of hybridization to which Stuart Hall refers in his text "The question of cultural identity"(1992). It also seeks to discover the historical and geographical context of this production as well as aspects related to Japanese immigration in the state, even before its emancipation.

\section{Introduction}

Since the beginning of the 20th century, with the curiosity of the Brazilian modernists about haiku (which they came to know through French authors), until the contemporary literary production of the nikkei writers, among whom we cite Oscar Nakasato (winner of the Jabuti Award 2012, a traditional literary award in Brazil), Laura Honda-Hasegawa and André Kondo, Japan and its culture (hence also its literature) have been in contact with Brazil in various ways and at various levels, especially - although not exclusively - thanks to the presence of Japanese immigrants and their descendants in Brazil.

It is up to the university, through research actions, to establish and foster possible dialogues between Japanese and Brazilian literature, whether about intertextual relations, translation studies, literary production of nikkei (Japanese descendants), or any other manifestations concerning the subject.

Regarding nikkei 's literary production in Brazil (mostly in the South and Southeast), there is already research, especially regarding writers with greater visibility. However, what can be said about the nikkei literary production in the state of Mato Grosso do Sul? Does it exist? If it exists, who are the writers? What are the characteristics of this production? This project arises from the need to know this production and study it as part of contemporary Brazilian literature. However, its authors are subjects linked to Japanese culture, extremely careful of traditional practices, and respectful of ancestry. This double heritage makes this production even richer and more peculiar.

In the city of Campo Grande, there is a significant presence of Okinawan descendants. Many immigrants came to the region at the time of the Northwest Brazil Railroad construction and settled in the city after the works were finished (BRAZIL'S OKINAWAN KENJIN ASSOCIATION, 2012, p. 85). It should be noted that, at the time, the division of the state into Mato Grosso and Mato Grosso do Sul had not yet occurred. Therefore, one of the aims of the research in its planning was to verify if, in the literary production found, there is any writing by the descendants of Okinawans and if this ascendancy is in any way reflected in writing or style.

\section{Development proposal}

When it comes to immigration studies and nikkei cultural manifestations, both mobility and integration are inherent concepts. The relevance of the proposed work is based on its intention to demonstrate these concepts by studying the literary production of a specific group of Japanese immigrants not yet studied (at least as far as research has been possible).

\section{K C AL-KINDI CENTER \\ R D PEVELOPMENT Your gateway to world-closs research}

Published by Al-KindiCenter for Research and Development. Copyright (c) the author(s). This is an open access article under CC BY license (https://creativecommons.org/licenses/by/4.0/) 
In order to know the literary production of the group on screen, it is necessary to investigate the existence of books publis hed by authors writing in Mato Grosso do Sul (not only born in the state). It must be taken into account that this is a recent state, dismembered from Mato Grosso in 1977, in a process that was only concluded in 1979. At the time of its emancipation, there was already a well-established nikkei community in the state.

\subsection{Objectives}

Based on the general objective of the research (to study the nikkei literary production in Mato Grosso do Sul), the following specific objectives were elaborated: 1 ) to research the literary production already carried out by nikkei writers in the state of Mato Grosso do Sul, either through published works or through initiatives such as meetings of haiku groups, promoted by the Sports and Cultural Association of Nikkei in Campo Grande; 2 ) to study the history of Japanese immigration in the state in the literary path of the descendants of the first immigrants; 3 ) to verify the presence of characteristics related to the Okinawa region, from where most of the immigrants who settled in Mato Grosso (even before Mato Grosso do Sul existed) came; 4) to analyze the literary production of nikkei in the state as a space for the manifestation of memory and the construction of identity; and 5) to promote the critical reading of nikkei writers as products of a process of cultural hybridism, as defined by Stuart Hall in his work "The question of cultural identity" (1992).

\subsection{Methodology}

The methodology adopted is exploratory bibliographic research. Besides the literary production itself (primary sources), documents and publications on Japanese immigration in Mato Grosso do Sul and books about Japanese immigration to the state (secondary sources) will be researched. The publications selected for the initial research are "The Okinawan immigrants from Kasato-Maru," "Land of Hope," and "Ayumi - the saga of the Japanese colony in Campo Grande" (see bibliography - titles in Portuguese with translation). If there are opportunities, interviews with the writers may be conducted, and published with permission in literary journals or other academic spaces.

As theoretical support for the research, Stuart Hall's study on cultural identity developed in his book "The question of cultural identity" (1992) serves as a basis. When it comes to writing about immigrants - or their descendants - this concept is essential, while understood as a synonym of national identity, as a reference to a homeland. For Seligmann-Silva, homeland "is a feeling of belonging; to be an immigrant is to lose that feeling and to be nostalgic about that loss" (2018, p. 156). In what way can this feeling be found in the nikkei literary production in the context of Mato Grosso do Sul? Is there a characteristic trait? In what ways does it present itself?

As a constructed element (social and individual) and a constituent of the feeling of identity (POLLAK, 1992, p. 204-205), the concept of memory is also fundamental for conducting this research. The association between memory and imagination, as developed by Gaston Bachelard, is also pertinent to the study we intend to conduct here since it is a literary production in which the lived/imagined/reflected culture finds space.

Within the spectrum of Japanese culture in general, the Okinawa culture has peculiar characteristics resulting from geographical distance and historical intervenient circumstances. In addition to researching nikkei literary production, the research also intends to study the process related to Okinawans' immigration, a significant presence in the state of Mato Grosso do Sul. Among the Japanese pioneers who came to Kasato Maru (a total of 781 people), 325 were from Okinawa Prefecture (OKINAWA ASSOCIATION OF CAMPO GRANDE, 2014, p. 65). Many of them, although initially hired to work in coffee plantations, worked on the construction of the railway between Porto Esperança (in the city of Corumbá) and Campo Grande, and between Bauru (in the state of São Paulo) and Campo Grande (Ibid., p. 69; AKAMINE, 2015, p.10). The Okinawa Association of Campo Grande was founded in 1922 (Ibid., p. 262).

\section{Progress of the research}

So far, we have visited the Sports and Cultural Association of Nikkei in Campo Grande (AECNB) and the Okinawa Association of Campo Grande to search for information and bibliographic material. The State Public Archive of Mato Grosso do Sul was also consulted, but it was impossible to find any literary work in their files. We visited the Historical Museum of Japanese Immigration in Brazil (São Paulo), where we obtained some bibliographical material about immigration in the state (not about nikkei literature), and we planned a visit to the Historical and Geographic Institute of Mato Grosso do Sul. However, the pandemic changed all the initial plans and chronogram, and the visit had to be delayed.

We have also researched the websites of UBE-MS (Brazilian Writers Union - Mato Grosso do Sul) and the Dourados Academy of Letters ("Academia Douradense de Letras"), but there is no nikkei associate member in any of them to the present 
moment. We also contacted the Academy of Brazilian Nikkei Writers, that reported that none of their participants is from Mato Grosso do Sul (nor Mato Grosso, the name of the state to which it belonged, before emancipation).

One of the possibilities suggested at the outlining of the project was to divide the research into two groups: one of the authors writing in Portuguese and the other of writers whose production was in Japanese. According to information received at the Japanese Colony Sports Association in Campo Grande, a haiku group used to meet at the Association's premises until about three years ago. Unfortunately, it seems that the group no longer meets, so it is unlikely (though not impossible) that there will be production in Japanese. This improbability then turns into a second research question, to be further addressed perhaps in a separate project.

At first, there was the thought of establishing the type of literary production that would integrate the corpus: would it be restricted to literary production purely and simply artistic (poems, short stories, novels, and so forth)? Or literary production of an instructive-informative nature (newspaper articles, weblog essays and similar texts)? Academic texts, in the scope of Languages/Literature, could be included in this corpus? The most comprehensive direction to follow seems to gather information about writers and works first, then divide them into groups (and subgroups, if necessary).

\subsection{Tentative list}

Up to now, we found only three names of nikkei authors in activity in the state of Mato Grosso do Sul. The first was born in the state, but the second and third came to the capital Campo Grande as adults, to work in the city. Here they are:

a. Danilo Gustavo Nuha - Journalist; author of the novel "Nada consta" ("Nothing on Record") and the biography "Milton Nascimento - letras, histórias e canções" ("Milton Nascimento - Lyrics, Stories and Songs"), about Brazilian singer Milton Nascimento.

b. Fábio Dobashi Furuzato - Graduated in Journalism and Letters. Professor at Mato Grosso do Sul State University (Letters). Author of "Diário de um hemorroidário: contra a vergonha e o preconceito" ("Journal of a Hemorroidal: Against Shame and Prejudice").

c. Henrique Komatsu - Writer; Graduated in Philosophy and Law. Author of the books "Gangorra" ("See-Saw"), "A menina que viu Deus" ("The Girl Who Saw God"), "Concerto para quatro mãos" ("Concert for Four Hands"), "Cidade Dormitório" ("Dormitory Village"), "A Igreja de pedra" (The Stone Church"), and "Ototo" ("Ototo" - the word for "younger brother" in Japanese). This last one was a finalist of Prêmio Jabuti ("Jabuti Prize") 2020, the most traditional literary award in Brazil.

\section{Conclusion}

We continue seeking more information about nikkei writers in activity in Mato Grosso do Sul. The 2020 pandemic affected the research plan's flow in a very drastic way, for the time reserved for reading and searching for writers had to be reallocated to other university activities (teaching online, preparing online classes, supervising students, participating in meetings, and so forth).

The tentative list is still small, and maybe it just reveals the reality - that there are not many nikkei writers in activity in the state nowadays. Since two of them came from other states, their works are not likely to attach to the aims of this research concerning the process of Japanese immigration in Mato Grosso do Sul. However, the first writer in the list, Danilo Gustavo Nuha, has a novel that is filled with personal reminiscences, a kind of memoir. He was adopted by a family of Okinawan descent, so it is very probable that his novel will help us accomplish objectives 3 to 5 of this research: to verify the presence of characteristics related to the Okinawa region in the writings, to analyze the literary production as a space for the manifestation of memory and the construction of identity, and to promote its reading as an evidence of cultural hybridism.

We are trying to find some more information about nikkei writers in other cities of the state - specially Dourados, in the center-south, where there is another nikkei association and a considerable number of people of Japanese descent. From now on, the research concentrates on the quest for other names until the end of the chronogram, established at first to June 2021, along with the reading of the books of the writers already found, in special Nuha's novel.

\section{Acknowledgments}

This study was financed in part by the Higher Education Improvement Coordination (Coordenação de Aperfeiçoamento de Pessoal de Nível Superior - CAPES - Brazil) - Finance Code 001. We thank the Federal University of Mato Grosso do Sul for supporting this paper publication through the Women in Science initiative (2020). 


\section{References}

[1] Akamine, S. (2015). Os imigrantes okinawanos do Kasato-Maru ("Kasato-Maru's okinawan immigrants"). São Paulo, Paulo's.

[2] ASSOCIAÇÃO ESPORTIVA DA COLÔNIA JAPONESA EM CAMPO GRANDE (SPORTS AND CULTURAL ASSOCIATION OF NIKKEI IN CAMPO GRANDE). (2005). Ayumi: a saga da colônia japonesa em Campo Grande (Ayumi: the saga of the Japanese colony in Campo Grande"). Campo Grande-MS, Saber Editora.

[3] ASSOCIAÇÃO OKINAWA DE CAMPO GRANDE (CAMPO GRANDE OKINAWA ASSOCIATION"). (2014). Terra de esperança, kibo no daitsi ("Land of Hope"). Campo Grande-MS, Life Editora.

[4] ASSOCIAÇÃO OKINAWANA KENJIN DO BRASIL (BRAZIL'S OKINAWAN KENJIN ASSOCIATION). (2012). 1 século de história: a comunidade okinawana no Brasil, desde o navio Kasato Maru (1908-2008) ("One century of history: the okinawan community in Brazil, since Kasato Maru (1908-2008)"). São Paulo, Paulo's.

[5] Bachelard, G. (1989). A poética do espaço ("The Poetics of Space"). São Paulo, Martins Fontes.

[6] Hall, S. (1992). The question of cultural identity. In: S. Hall, D. Held e T. McGrew. Modernity and its features. Politic Press/Open University Press.

[7] Pollak, M. (1992). Memória e identidade social. Revista Estudos Históricos, 5(10), 200-215.

[8] Seligmann-Silva, M. (2005). O local da diferença: ensaios sobre memória, arte, literatura e tradução 